\title{
Co-inoculation of phosphate solubilizing bacteria and Rhizobia for improving growth and yield of mungbean (Vigna radiata $\mathrm{L}$.)
}

\author{
H.K. TARAFDER, A. DEY AND S. DASGUPTA
}

Received : 16.02.2016; Revised : 22.04.2016; Accepted : 18.05.2016

MEMBERS OF RESEARCH FORUM:

Corresponding author : H. K. TARAFDER, Regional Research Station (U.B.K.V.) (Hill Zone) Kalimpong, DARJEELING (W.B.) INDIA Email: hridaykamalt25@gmail.com

Co-authors :

A. DEY, Regional Research Station (B.C.K.V.), New Alluvial Zone, Gayeshpur, NADIA (W.B.) INDIA

Email: arupdey89@gmail.com

S. DASGUPTA, AICRP on STCR, Directorate of Reserach, Bidhan Chandra Krishi Viswavidyalaya, Kalyani, NADIA (W.B.) INDIA Email: sdasgupta173@gmail.com

\section{Summary}

Mung bean is an important pulse crop in West Bengal, growing nearly 11.7 thousands hectares of land. Scientific literature and case studies of inoculating of microbes by various scientists found significant response to crop growth. The present study was made to reduce fertilizer application rate by coinnoculating phosphate solubilizing bacteria and rhizobia for mung bean. The experiment was conducted in the year 2011 and 2012 at the 'Instructional Farm' Bidhan Chandra Krishi Viswavidyalaya, Mohanpur, Nadia, West Bengal. Factorial Randomized Block Design was laid out with three replications and 10 treatment combinations. The treatments was without inoculation $\left(\mathrm{A}_{0}\right)$ and seed inoculation with Rhizobium and phosphate solubilizing bacteria (PSB) strain $\left(\mathrm{A}_{1}\right)$ as factor one and fertilizer treatments like untreated control (no fertilizer application $\mathrm{B}_{0}$ ), application of NPK (recommended dose as basal $\mathrm{B}_{1}$ ), 75 per cent recommended dose of $\mathrm{N}_{\text {and }} \mathrm{P}_{2} \mathrm{O}_{5}+100 \% \mathrm{~K}_{2} \mathrm{O}\left(\mathrm{B}_{2}\right)$ and 50 per cent recommended dose of $\mathrm{N}$ and $\mathrm{P}_{2} \mathrm{O}_{5}+100 \% \mathrm{~K}_{2} \mathrm{O}\left(\mathrm{B}_{3}\right)$. It was observed that inoculation with Rhizobium and phosphate solubilizing bacteria (PSB) along with 75 per cent RDF i.e. treatment combination $\left(\mathrm{A}_{1} \mathrm{~B}_{2}\right)$ was at par with treatment $\mathrm{A}_{1} \mathrm{~B}_{1}$ i.e. 100 per cent RDF with respect to all the growth parameters and yield attributing characters of mung bean. So, it can be concluded that both 25 per cent nitrogenous and phosphatic fertilizer of the recommended dose can be substituted by seed co-inoculation with phosphate solubilizing bacteria and rhizobia without affecting the yield compared to 100 per cent RDF.

Key words : Bacillus polymyxa, Rhizobia, Mung bean, Seed inoculation

How to cite this article : Tarafder, H.K., Dey, A. and Dasgupta, S. (2016). Co-inoculation of phosphate solubilizing bacteria and Rhizobia for improving growth and yield of mungbean (Vigna radiata L.). Asian J. Soil Sci., 11 (1) : 207-212 : DOI : 10.15740/HAS/AJSS/11.1/207-212. 